\title{
Introducing the Forum on the Friendship Between Sigmund Freud and Oskar Pfister
}

\author{
Isabelle Noth
}

Published online: 27 July 2013

(C) Springer Science+Business Media New York 2013

In contrast to the importance that Oskar Pfister gave to the life of Sigmund Freud, the unusual relationship between the Swiss Reformed pastor and the Austrian Jewish psychiatrist has not evoked much interest in theological or psychoanalytic research. Although Pfister is not very well known in theological circles, even in his own country, the American Psychiatric Association (APA) presents an annual "Oskar Pfister Award". Among the recipients of this award are Viktor Frankl, Hans Küng, Paul Ricoeur, Ann Ulanov, Abraham Twerski, and Ana-Maria Rizzuto. The lack of scholarly interest can be traced back historically in Switzerland to the initial theological hesitations concerning psychoanalysis. Despite all his investigations to make psychoanalysis useful as a therapeutic method for pastoral care, and despite all his many publications, Oskar Pfister was forgotten. This occurred despite the fact that it was Freud himself who, writing to Pfister on 9 February 1909, said, "I am surprised that I myself had never thought what great help the psychoanalytic method could be for pastoral care".

Pfister was a very convinced follower of Freud but remained always critical of Freud's theories of religion. It is astonishing that in the jubilee year of 2006 (150th anniversary of Freud's birth) not one single conference in Europe or the United States was devoted to this extraordinary friendship between the atheist and the pastor. But when the Swiss Oskar Pfister wrote an early introduction to psychoanalysis, Freud contributed a preface (Oskar Pfister, Die psychanalytische [sic] Methode, Leipzig, 1913). After the publication of Freud's The Future of an Illusion in 1927, Pfister wrote a response, which Freud published in 1928 in Imago. Its title, "The Illusion of a Future", illustrates their friendly relationship that thrived on intellectual debate. This particular debate on their contrasting theories of religion did not lead to a break in the relationship between Freud and Pfister.

In order to remedy the lack of scholarly attention paid to this special friendship and debate, Isabelle Noth and Christoph Morgenthaler held a conference in 2006 at the University of Bern on "Sigmund Freud (1856-1939)-Oskar Pfister (1873-1956): The Beginnings of the Theological Reception of Psychoanalysis in Switzerland". This conference, using accessible sources, brought new insights to bear on the relationship between Freud and Pfister and on Pfister's concept of analytic pastoral care. The lectures were published in 2007 (Isabelle Noth and Christoph Morgenthaler, eds., Seelsorge und Psychoanalyse, Stuttgart: Kohlhammer-Verlag, 2007).

\section{Noth $(\square)$}

Theology Faculty, University of Bern, Unitobler,

Länggassstrasse 51, CH-3000 Bern 9, Switzerland

e-mail: isabelle.noth@theol.unibe.ch 
On November 18, 2011, the Psychology, Culture \& Religion Group held a pre-session at the American Academy of Religion Annual Meeting in San Francisco on "The Friendship between Sigmund Freud and Oskar Pfister as Seen in the Correspondence between the Jewish Atheist Founder of Psychoanalysis and the Swiss Pastor who Pioneered Pastoral Psychology". Presenters were Isabelle Noth (Zurich) and Christoph Morgenthaler (Bern), who will publish the new edition of the whole annotated correspondence between Freud and Pfister, and the respondents were Pamela Cooper-White (Columbia Theological Seminary) and Herman Westerink (Vienna). We are delighted to share these papers with the readers of Pastoral Psychology. 